\title{
ПЕДІАТРІЯ
}

UDC: $611: 378.147$

DOI: $10.26565 / 2617-409 X-2018-1-06$

\section{SIMULATION-BASED MEDICAL TEACHING AND LEARNING IN HUMAN ANATOMY}

\author{
S. A. Sherstiuk, Ye. O. Zubova, S. A. Nakonechna. \\ Харьковский национальный университет имени В.Н. Каразина, Украина
}

Modern medical education faces a problem of combining the latest technology with classic teaching methods. Simulation is a technique, which replaces or amplifies experiences in controlled conditions and therefore evokes or replicates substantial aspects of the real world in a fully interactive manner. The basic course of human anatomy in medical education could be recognised as the best example of implementing new educational techniques such as simulation, into the traditional medical curriculum.

Key words: human anatomy, simulation, cadaver, dissection, medical students

\section{Introduction.}

Discussions about dissection as a teaching method in gross anatomy are characterised by a lack of objective evidence. Considering the bias that must be assumed for teachers who develop new course designs and compare these with traditional ones, the review shows a slight advantage for traditional dissection over prosection. More sophisticated research designs may be necessary to solve the general problem of the small measurable impact of educational interventions and to come to scientifically sound conclusions about the best way to teach gross anatomy. Such research will have to include sufficient sample sizes, the use of validated assessment instruments, and a discussion of the educational significance of measured differences. More educational research in anatomy is necessary to counterbalance emotional arguments about dissection with scientific evidence. Anatomical knowledge is too important to future doctors to leave its teaching to the educational fashion of the day.

Cadaver dissection has been an important component in the traditional method of teaching human anatomy in Medical Faculties. However, today many Medical Institutions are facing with practical constraints associated with cadaver dissection. Cadaver dissection takes up a lot of time. This directly conflicts with the changes that have been made in the medical curricula limiting the time available for teaching human anatomy. Availability of cadavers to accommodate the growing number of medical students. As a result, anatomy teachers are seeking novel teaching methods to keep up with the changes in the circumstances.

\section{Discussion.}

Modern medical education faces a problem of combining the latest technology, procedures and information with classic teaching methods. The goal is to prepare students to become physicians equipped with the latest conceptions in medicine. Another challenge is the linking of theoretical and practical knowledge without forgetting the socio-practical aspect of medical care. 
Training, from the very beginning, taking place in a reality-reflected environment (e.g. simulationbased training) seems to be a beneficial solution. Simulation is a technique, which replaces or amplifies doctor-patient experiences in controlled conditions and therefore evokes or replicates substantial aspects of the real world in a fully interactive manner [1]. Simulation techniques improve both cognitive and practical aspects of the education process in predictable and stress free conditions.

The basic course of anatomy in medical education could be recognised as the best example of implementing new educational techniques such as simulation, into the traditional medical curriculum.

Different simulation techniques are used with different intensity; however cadaveric dissection is still the most popular method. The second most frequent method is simulation-based training. The role of the classical educational method in the curriculum of human anatomy has changed nowadays. The students' role has changed from passive observers to active participants, who want to know more than «where is it» or «what is it relation to other structures». The main aim of cadaveric dissection is to show that anatomical knowledge can be useful in the practice of real medicine. Academics highlight the fact that dissection may impart anatomical knowledge as well as offer other relevant, positive learning opportunities to enhance skills and attitude of future physicians [2]. Specifically, the human anatomy course has a strong emotional influence on young people who want to be physicians. Knowledge and skills like: teamwork, stress coping strategies, empathy, respect for the human body, theory and practice integration with preparation for clinical studies are taught during the dissection course $[2,3]$.

It has been reported that during undergraduate medical education, the trainee should not only gain theoretical knowledge but also acquire essential skills [4]. What is more, the students' interest rate level in studying anatomy increased substantially when the clinical aspects were introduced into the course [5].

Another way to improve anatomical curriculum is to make laboratory time more interesting and to encourage discussion. Some universities create specially designed aim-focused tasks which are given to students during dissection. These tasks were assigned to students throughout dissection or built dissection teams which aim is to identify lists of structures given on the day of dissection [6, 7]. The cadaveric specimens may be replaced by the plastinated prosections. This technique shows with details all structures and relations between them [8]. The last branch of modern anatomical curriculum is radiological anatomy using images based on cadavers. The leaders of this procedure claimed that radiological images show anatomical structures in multiple planes and may be effective in the teaching of anatomical spatial relationships, which happens to be the most difficult for students [9]. This tool not only enables the scanning of the whole body but also creates virtual patient imaging and develops interactive simulation programs for clinical practice [10].

Simulators used in the teaching of human anatomy may be classified into different categories. The division depends on the level of reality, partial or holistic view on human's body or interactions with surroundings $[11,12]$. An example of these are the high-fidelity parts of the body manikins with very basic application to demonstrate or indicate anatomical structures and the Human Patient Simulator which is one of the most impressive high- -fidelity whole body manikins [13, 14].

Interactive programs visualising anatomy are becoming more popular. The number of hours of human anatomy in the medical curricula decreases systematically pread this wisdom and way of being to theirs students. Dissection seems to be present in the anatomy curriculum from the beginning. However, cadaveric dissections have some limitations such as those connected with cadavers like colour, smell, inability to change the position or being auscultated and connected with ethics and legacy [15]. That is why simulation techniques seem to be helpful and partially may replace the cadavers. In the future, the anatomy curriculum will be connected with increasing number of modern technologies 
A state of the art anatomical curriculum offers numerous possibilities and solutions including the oldest like cadaveric dissection and newest like simulators.

Conclusions. To conclude it can be said that new technologies are supportive and beneficial in human anatomy teaching however each excitement of new technologies sometimes should be tempered and evaluated for its usefulness in making the learning process constructive for students and their future practice.

\section{References.}

1. Gaba D. The future vision of simulation in health care / D. Gaba. // Qual Saf Health Care. - 2004. V. 13. - P. 2-10.

2. Lempp H.K. Perceptions of dissection by students in one medical school: beyond learning about anatomy / H.K. Lempp // A qualitative study. Med Educ. - 2005. - № 39. - P. 318-325.

3. The gross anatomy course: an analysis of its importance / A. Bockers, L. Jerg-Bretzke, C. Lamp, A. Brinkmann, H. Traue, T. Bockers // Anat Sci Educ. - 2010. - V. 3. P. 3-11.

4. Training of practical clinical skills in surgery: a training concept for medical students / M. Russeler, R. Weber, A. Braunbeck, W. Flaig // Lehrteam des Zentrum Chirurgie, Zentralbl Chir. - 2011. - № 135. - P. 249-256.

5. Enhancing Preclinical Education in Japan with a Clinically Focused / H. Kanchan Rao, R. Harsha Rao // Perspectives in Medical Education, Interactive Anatomy Curriculum. Keio J Med. - 2009. - № 58. - P. 210-215.

6. Using checklists in a gross anatomy laboratory improves learning outcomes and dissection quality / R. Hofer, O. Nikolaus, W. Pawlina // Anat Sci Educ. - 2001. - V. 4. - P. 249-255.

7. The use of specially designed tasks to enhance student interest in the cadaver dissection laboratory / S. Kang, J. Shin, Y. Hwang // Anat Sci Educ. 2012. - V. 5.- P. 76-82.

8. The use of plastinated prosections for teaching anatomy: the view of medical students on the value of this learning resource / B. Fruhstorfer, J. Palmer, S. Brydges, P. Abrahams // Clin Anat. - 2001. - № 24. - P. 246-252.

9. Incorporating radiology into medical gross anatomy: does the use of cadaver CT scans improve students' academic performance in anatomy / R. Lufler, A. Zumwalt, C. Romney, T. Hoagland // Anat Sci Educ. 2010. - V. 3. - P. 56-63.

10. Advanced features of whole body sectioned images / L. Tang, M. Chung, Q. Liu, D. Shin // Virtual Chinese Human. Clin Anat. 2010. - № 23. - P. 523-529.

11. Maran N. Low-to high-fidelity simulation: a continuum of medical education / N. Maran, R. Glavin // Med Edu. 2003. - № 37. - P. 22-28.

12. Simulation: not just a Manikin / M. Seropian, K. Brown, J. Gavilanes, B. Driggers // Nurs Educ. 2004. - № 43. - P. 164-169.

13. Al-Elq A.H. Simulation-based medical teaching and learning / A.H. Al-Elq // J. Family Community Med. - 2010. - V. 17. - P. 35-40.

14. Endoscopic sinus surgery simulator as a teaching tool for anatomy education / A. Solyar, H. Cuellar, B. Sadoughi, T. Olson, M. Fried // Am J Surg. - 2008. - V. 196. - P. 120-124.

15. McLachlan J. New path for teaching anatomy: living anatomy and medical imaging vs. dissection / J/ McLachlan // Anat Rec B New Anat. - 2004. - V. 281. - P. 4-5. 


\section{СИМУЛЯТИВНЫЙ МЕТОД МЕДИЦИНСКОГО ПРЕПОДАВАНИЯ И ИЗУЧЕНИЯ АНАТОМИИ ЧЕЛОВЕКА}

\section{С. А. Шерстюк, Е. О. Зубова, С. А. Наконечная.}

Современное медицинское образование сталкивается с проблемой сочетания новейших технологий с классической методикой преподавания. Симуляция- это метод, который заменяет или усиливает навыки в контролируемых условиях и поэтому вызывает или повторяет существенные аспекты реального мира в полностью интерактивной манере. Базовый курс анатомии человека в медицинском образовании может быть признан лучшим примером внедрения новых образовательных методов, таких как симуляция, в традиционную учебную программу.

Ключевые слова: анатомия человека, симуляция, труп, вскрытие, студенты-медики.

\section{СИМУЛЯЦЙНИЙ МЕТОД МЕДИЧНОГО ВИКЛАДАННЯ ТА ВИВЧЕННЯ АНАТОМІЇ ЛЮДИНИ}

\section{С. О. Шерстюк, С. О. Зубова, С. А. Наконечна.}

Сучасна медична освіта стикається із проблемою поєднання новітніх технологій 3 класичною методикою викладання. Симуляція - це метод, який заміняє або посилює навички у контролюємих умовах і тому викликає або повторює суттєві аспекти реального світу в повністю інтерактивній манері. Базовий курс анатомії людини в медичній освіті може бути визнаний кращим прикладом внедріння нових освітніх методів, таких як симуляція, в традиційну навчальну програму.

Ключові слова: анатомія людини, симуляція, труп, розтин, студенти-медики. 